\title{
Biological aspects of the beetle Delphastus davidsoni fed with whitefly eggs laid on tomato genotypes
}

\author{
Maria Auxiliadora de Godoy Oriani, José Djair Vendramim*
}

University of São Paulo/ESALQ - Dept. of Entomology and Acarology, C.P. 9 - 13418-900 - Piracicaba, SP - Brazil.

*Corresponding author <jdvendra@usp.br>

Edited by: Richard V. Glatz
ABSTRACT: Many plant breeding programs have incorporated plant resistance characteristics without considering how this resistance may affect the natural enemies of plant pests. We evaluated the biological aspects of Delphastus davidsoni (Gordon) fed with Bemisia tabaci B biotype eggs laid on tomato genotypes with different trichome densities and types. On LA1335 and NAV1062, the development periods were 21 days, and the larval mortality rates were $46.7 \%$ and $28.9 \%$, respectively; on IAC294, the development period was 26 days, and the mortality rate $88.9 \%$. None of the larvae completed development when fed with whitefly eggs laid on PI134418. Most of the deaths took place in the second instar stage because the larvae became trapped in the glandular trichomes; similar results were also observed on IAC294. The adult longevity and female fecundity on LA1335 and NAV1062 were 32 and 34 days, and 61 and 78 eggs, respectively. The type IV and VI glandular trichomes present on PI134418 and IAC294 adversely affected the larval development of $D$. davidsoni, resulting in high mortality rates. Nevertheless, type V non-glandular trichomes, in high (NAV1062) or low (LA1335) densities, did not affect the development of the insect.

Keywords: Solanum lycopersicum, lady beetle, plant resistance, trichomes, tritrophic interaction tion, foraging behavior, attachment to the plant and oviposition of phytophagous and predaceous insects $(\mathrm{Ob}$ rycki and Tauber, 1984).

In Solanum lycopersicum (=Lycopersicon esculentum Mill) (Peralta et al., 2006), type V trichome density is positively related to $B$. tabaci oviposition (Heinz and Zalom, 1995; Snyder et al., 1998), and type IV and VI glandular trichomes cause antixenosis for oviposition (Muigai et al., 2002; Oriani and Vendramim, 2010; Oriani et al., 2011a). Trichomes may also influence the searching behavior of natural predators (Hare, 1992; Guershon and Gerling, 2006), and predator efficiency may be adversely affected due to an increase in searching time for the prey (Botrell et al., 1998). The predation of D. pusillus is higher on hosts with lower trichome densities (Heinz et al., 1994), although its ability to suppress B. tabaci B biotype populations is unaffected by tomato pubescence (Heinz and Zalom, 1996).

We evaluated the development period and viability of each immature phase, and the adult longevity and fecundity of $D$. davidsoni fed with $B$. tabaci B biotype eggs laid on tomato genotypes with different trichome densities and types.

\section{Materials and Methods}

The experiments were carried out under controlled laboratory conditions $\left(23 \pm 2{ }^{\circ} \mathrm{C}, 70 \pm 10 \% \mathrm{RH}\right.$ and a photophase of $13 \mathrm{~h}$ ). Four tomato genotypes were chosen based on differences in the densities and types of trichomes, levels of antixenosis for oviposition (Oriani and Vendramim, 2010; Oriani et al., 2011a) and levels of feeding non-preference and/or antibiosis-based resistance (Oriani et al., 2011b) to B. tabaci B biotype. The 
chosen genotypes were: i) NAV1062 (S. pimpinellifolium = L. pimpinellifolium) - low degree of antixenosis for oviposition, low degree of feeding non-preference and/or antibiosis, and high density of type $\mathrm{V}$ non-glandular trichomes; ii) LA1335 (S. pimpinellifolium) - low degree of antixenosis for oviposition, high degree of feeding non-preference and/ or antibiosis, and low density of type $\mathrm{V}$ non-glandular trichomes; iii) PI134418 (S. habrochaites f. glabratum $=L$. hirsutum f. glabratum) - high degree of antixenosis for oviposition, low degree of feeding non-preference and/or antibiosis, and high density of type IV glandular trichomes; and iv) IAC294 (S. habrochaites f. glabratum) - low degree of antixenosis for oviposition, low degree of feeding non-preference and/or antibiosis, and medium density of type IV glandular trichomes.

A whitefly stock colony was drawn from a population characterized as $B$. tabaci (B biotype). The insects were reared on soybean [Glycine max (L.) Merrill] and painted spurge (Euphorbia heterophylla L.) plants kept in a greenhouse with anti-aphid screens. A portion of the reared whiteflies was used for $D$. davidsoni feeding. Because a large number of beetle larvae pupated inside crevices on the sides and bottoms of the plant pots, they were maintained in the rearing cage until adults emerged (Pickett et al., 1999).

The trials were set up in a randomized block design with 45 replicates for each tomato genotype. Each replicate consisted of one neonate larva in its own feeding arena. $D$. davidsoni larvae were fed daily ad libitum with 1-2-day-old whitefly eggs laid on four tomato genotypes. Leaflets with petioles wrapped with humidified cotton containing whitefly eggs were placed in plastic Petri dishes of $7.5 \mathrm{~cm}$ in diameter. The leaflets containing at least 100 whitefly eggs were replaced at 2-day intervals. The development period and viability of each immature life stage of $D$. davidsoni were evaluated every 24 hours. The end of each instar stage was determined when an exuvia was found.

Recently emerged males and females fed with whitefly eggs laid on each tomato genotype were individually placed in plastic cages $(16 \mathrm{~cm}$ in height and $13 \mathrm{~cm}$ in diameter). The cage had a plastic lid with a 6 $\mathrm{cm}$ diameter hole that was covered with an anti-aphid screen to allow airflow into the cage. The leaves were placed in a 5-cm-long plastic hose filled with distilled water attached to the inner wall of the cage. Until their death, the insects were daily fed ad libitum with whitefly eggs laid on soybean leaves. Females were confined with two or three males over $24 \mathrm{~h}$ for mating, after which the males were removed. For evaluation purposes, the leaves were observed under a stereoscopic microscope, and the daily oviposition and male and female survival were determined.

Completely expanded apical leaflets of five tomato plants were collected (means calculated from five samples of each cultivar at two ages: 45 and 60 days old). The trichome types were counted using a microscope (at 100x magnification). For this procedure, semi-perma- nent glass slides for each leaflet were prepared using the epidermal fingerprint technique (Segatto et al., 2004), and the trichome densities were calculated according to McAuslane (1996).

The data obtained were first analyzed using Bartlett's test of homoscedasticity, transformed as needed, and then subjected to analysis of variance by the Ftest. The means were compared using Tukey's test $(p \leq$ 0.05).

\section{Results and Discussion}

The incubation period of $D$. davidsoni eggs varied between 6.6 (LA1335 and IAC294) and 6.7 (NAV1062 and PI134418) days. Larvae fed with whitefly eggs laid on NAV1062 and LA1335 genotypes presented shorter development (10.4 and 10.8 days, respectively) than the larvae fed whiteflies eggs laid on IAC294 (13.6 days). The same tendency was found for pupal phase duration, which was shorter for the NAV1062 and LA1335 genotypes (4.4 and 4.7 days, respectively) than for the IAC294 genotype (5.0 days). Consequently, the total development period was shorter on NAV1062 (21.3 days) and LA1335 (21.4 days) and approximately $20 \%$ longer on IAC294 (25.6 days) (Table 1). Hoelmer et al. (1993) also observed a total development period of 21.0 days for D. pusillus. Furthermore, none of the larvae present on PI134418 completed development (Table 1).

Out of a total of $135 \mathrm{D}$. davidsoni larvae, $98 \%$ presented four larval instar stages; $2 \%$ went through a fifth instar stage, but none of them completed their development (Table 2). Hoelmer et al. (1993) observed that $50 \%$ of the larvae reached the pupal phase after four instars, and $50 \%$ completed a fifth larval instar stage. The third instar stage was longer on IAC294 (3.1 days) (Table 2), which influenced its superior development period $(25.6$ days) (Table 1). On the PI134418 genotype, the first instar stage (1.3 days) was shorter than on the other genotypes. In addition, out of 45 larvae on this genotype, only two completed the second instar stage.

Similarly, the development time of $D$. pusillus on hibiscus as a host plant at $28{ }^{\circ} \mathrm{C}$ was $4.1,1.8,1.4,1.8$, $1.7,2.0$ and 2.9 days for eggs, first, second, third, fourth fifth instars, pre-pupae and pupae, respectively, with an average of 21.0 days from oviposition to adulthood (Hoelmer et al., 1993). On collards, Liu (2005) observed development times of 4.0,1.9, 1.1, 1.4, 5.2, and 5.3 days, respectively, for eggs, first, second, third, and fourth instars, and pupae, with an average of 18.9 days from oviposition to adult emergence for both sexes (19.0 days for females, 18.8 days for males). As regards the effects of the temperature on developmental time of Delphastus, Legaspi et al. (2008) determined that as the temperature increased from 22 to $30^{\circ} \mathrm{C}$, the developmental time from eggs to adult emergence decreased from 24 to 15 days.

The sex ratio was $1: 1$ on the NAV1062 and LA1335 genotypes. Only five individuals (two males, three females) reached the adult phase on IAC294. There were 
Table 1 - Development of Delphastus davidsoni ( \pm SE) fed ad libitum with Bemisia tabaci B biotype eggs laid on four tomato genotypes.

\begin{tabular}{|c|c|c|c|c|}
\hline \multirow[t]{2}{*}{ Genotypes } & \multicolumn{4}{|c|}{ Development period (days) ${ }^{1}[\mathrm{n}]$} \\
\hline & Eggs & Larvae & Pupae & Total \\
\hline NAV1062 & $\begin{array}{c}6.7 \pm 0.14 \\
{[45]}\end{array}$ & $\begin{array}{c}10.4 \pm 0.35 a \\
{[35]}\end{array}$ & $\begin{array}{c}4.4 \pm 0.15 \mathrm{a} \\
{[32]}\end{array}$ & $\begin{array}{c}21.3 \pm 0.29 a \\
{[32]}\end{array}$ \\
\hline LA1335 & $\begin{array}{c}6.6 \pm 0.13 \\
{[45]}\end{array}$ & $\begin{array}{c}10.8 \pm 0.44 \mathrm{a} \\
{[28]}\end{array}$ & $\begin{array}{c}4.7 \pm 0.16 \mathrm{a} \\
{[24]}\end{array}$ & $\begin{array}{c}21.4 \pm 0.41 \mathrm{a} \\
{[24]}\end{array}$ \\
\hline IAC294 & $\begin{array}{c}6.6 \pm 0.15 \\
{[45]}\end{array}$ & $\begin{array}{c}13.6 \pm 0.75 b \\
{[7]}\end{array}$ & $\begin{array}{c}5.0 \pm 1.00 \mathrm{~b} \\
{[5]}\end{array}$ & $\begin{array}{c}25.6 \pm 1.33 b \\
{[5]}\end{array}$ \\
\hline Pl134418 & $\begin{array}{c}6.7 \pm 0.14 \\
{[45]}\end{array}$ & - & - & - \\
\hline Mean & 6.7 & 11.6 & 4.7 & 22.8 \\
\hline $\mathrm{F}$ & $0.25^{\mathrm{NS}}$ & $6.25^{*}$ & $1.15^{*}$ & $11.44^{*}$ \\
\hline CV (\%) & 13.9 & 7.6 & 21.6 & 8.9 \\
\hline
\end{tabular}

Means followed by the same letters within columns are not different (Tukey test, $p \leq 0.05$ ); ${ }^{1}$ Original data; transformed in $(x+3)^{1 / 2}$ for analysis; ${ }^{*}$ Significant at $p \leq$ 0.05; NS - Not significant at $p \leq 0.05$; [n] - Replicates.

Table 2 - Duration (days) of larval and pre-pupal stages of Delphastus davidsoni ( \pm SE) fed ad libitum with Bemisia tabaci B biotype eggs laid on four tomato genotypes.

\begin{tabular}{|c|c|c|c|c|c|}
\hline \multirow[t]{2}{*}{ Genotypes } & \multicolumn{4}{|c|}{ Instar development (days) ${ }^{1}[\mathrm{n}]$} & \multirow[t]{2}{*}{ Pre-pupae } \\
\hline & $1^{\text {th }}$ & $2^{\text {nd }}$ & $3^{\text {rd }}$ & $4^{\text {th }}$ & \\
\hline NAV1062 & $\begin{array}{c}2.3 \pm 0.17 \mathrm{a} \\
{[45]}\end{array}$ & $\begin{array}{c}1.7 \pm 0.10 \\
{[40]}\end{array}$ & $\begin{array}{c}2.1 \pm 0.14 \mathrm{a} \\
{[38]}\end{array}$ & $\begin{array}{c}2.9 \pm 0.17 \\
{[37]}\end{array}$ & $\begin{array}{c}1.7 \pm 0.17 \\
{[35]}\end{array}$ \\
\hline LA1335 & $2.4 \pm 0.17 \mathrm{a}$ & $\begin{array}{c}2.1 \pm 0.21 \\
{[33]}\end{array}$ & $\begin{array}{c}2.2 \pm 0.15 a b \\
{[31]}\end{array}$ & $\begin{array}{c}3.2 \pm 0.21 \\
{[31]}\end{array}$ & $\begin{array}{c}1.5 \pm 0.21 \\
{[28]}\end{array}$ \\
\hline IAC294 & $\begin{array}{c}2.1 \pm 0.16 \mathrm{ab} \\
{[45]}\end{array}$ & $\begin{array}{c}2.4 \pm 0.16 \\
{[15]}\end{array}$ & $\begin{array}{c}3.1 \pm 0.61 b \\
{[12]}\end{array}$ & $\begin{array}{c}3.4 \pm 0.34 \\
{[9]}\end{array}$ & $\begin{array}{c}2.6 \pm 0.57 \\
{[7]}\end{array}$ \\
\hline PI134418 & $\begin{array}{c}1.3 \pm 0.07 \mathrm{~b} \\
{[45]}\end{array}$ & $\begin{array}{c}1.0 \mathrm{a} \\
{[2]}\end{array}$ & - & - & - \\
\hline Mean & 2.0 & 1.8 & 2.5 & 3.2 & 1.9 \\
\hline $\mathrm{F}$ & $10.16^{*}$ & $3.34^{\mathrm{NS}}$ & $3.76^{\star}$ & $1.81^{\mathrm{NS}}$ & $2.64^{\mathrm{NS}}$ \\
\hline CV (\%) & 48.8 & 44.9 & 49.5 & 41.5 & 10.7 \\
\hline
\end{tabular}

Means followed by the same letters within columns are not different (Tukey test, $p \leq 0.05$ ); ${ }^{1}$ Original data; transformed in $(x+3)^{1 / 2}$ for analysis; ${ }^{*}$ Significant at $p \leq$ 0.05; NS - Not significant at $p \leq 0.05 ;$ [n] - Replicates.

no differences in longevity or fecundity for insects reared on NAV1062 and LA1335 genotypes. Although longevity was not statistically compared between males and females, similar values were found for both sexes (33 days for females and 30 days for males) (Table 3). Hoelmer et al. (1993) and Heinz et al. (1994) found shorter longevity for males (44.8 and 36 days, respectively) than females (around 60 days). The fecundity was 77.7 eggs for females reared on NAV1062 and 60.8 eggs on LA1335 (Table 3). Additionally, Heinz and Zalom (1996) found that $D$. pusillus on a glabrous tomato cultivar had greater lifetime fecundity than beetles on a pubescent tomato cultivar, while no difference between the adult longevities on the two tomato cultivars was found. For statistical analysis, however, the longevity and fecundity of emerged adults reared on IAC294 genotype were not considered because only one adult was observed; all other insects died during emergence, and two of them presented wing deformations.

Larval mortality was highest on the PI134418 genotype $(100 \%)$, followed by the IAC294 genotype (89 \%), and lower on the LA1335 (47\%) and NAV1062 genotypes $(29 \%)(F=2.44, C V=34.82, p \leq 0.05)$. As regards the mortality on each larval instar, significantly, mortalities occurred only in the first-instar on PI134418 (96\%) and IAC294 (64\%), which differed from the patterns observed on NAV1062 (11\%) and LA1335 (27 \%) (F $=27.00, C V=42.22, p \leq 0.05$ ) (Figure 1). This mortality was especially due to the larvae becoming trapped in the glandular trichomes. Moreover, the larvae rarely tolerated remaining on IAC294 and PI134418 leaflets and were constantly moving around the plastic dish, which precipitated their mortality. Predation may be influenced by the volatile compounds emitted by foliage or by the effects of plant architecture on foraging coccinellids (Legaspi et al., 2006). There was no mortality in neither the egg phase nor the pupal phase in any of the treatments evaluated (Figure 1).

S. lycopersicum has seven trichome types that were labeled from I to VII by Luckwill (1943). This classification is based on length and on the presence or absence of glandules in the apical extremity. Nonglandular trichomes (II, III and V) are highly similar to each other, differing only in length; out of these, type $\mathrm{V}$ is the shortest nonglandular trichome and the most commonly found on tomato leaves. Glandular trichomes (I, IV, VI 
Table 3 - Longevity (days) and fecundity (egg/female) of Delphastus davidsoni ( \pm SE) fed ad libitum with Bemisia tabaci B biotype eggs laid on four tomato genotypes.

\begin{tabular}{|c|c|c|c|c|}
\hline \multirow{2}{*}{ Genotypes } & \multicolumn{3}{|c|}{ Longevity [n] } & \multirow{2}{*}{ Fecundity ${ }^{1}[n]$} \\
\hline & Adults $^{1}$ & Female $^{2}$ & $\mathrm{Male}^{2}$ & \\
\hline NAV1062 & $34.0 \pm 3.41[21]$ & $33.2 \pm 4.51[15]$ & $31.7 \pm 4.51[6]$ & $77.7 \pm 10.98[15]$ \\
\hline LA1335 & $32.1 \pm 3.67[21]$ & $33.0 \pm 4.59[12]$ & $28.2 \pm 5.72[9]$ & $60.8 \pm 16.51$ [12] \\
\hline IAC294 & $46.0[1]$ & $46.0[1]$ & - & $82.0[1]$ \\
\hline PI134418 & - & - & - & - \\
\hline $\bar{F}$ & $0.44^{\mathrm{NS}}$ & $0.28^{\mathrm{NS}}$ & $0.38^{\mathrm{NS}}$ & $1.30^{\mathrm{NS}}$ \\
\hline CV (\%) & 28.6 & 27.1 & 30.2 & 44.8 \\
\hline
\end{tabular}

Means followed by the same letters within columns are not different (Tukey test, $p \leq 0.05$ ); ${ }^{1}$ Original data; without transformation for analysis; ${ }^{2}$ Original data; transformed in $(x+3)^{1 / 2}$ for analysis; *Significant at $p \leq 0.05$; NS - Not significant at $p \leq 0.05$; - Not considered for analysis; [n] - Replicates.

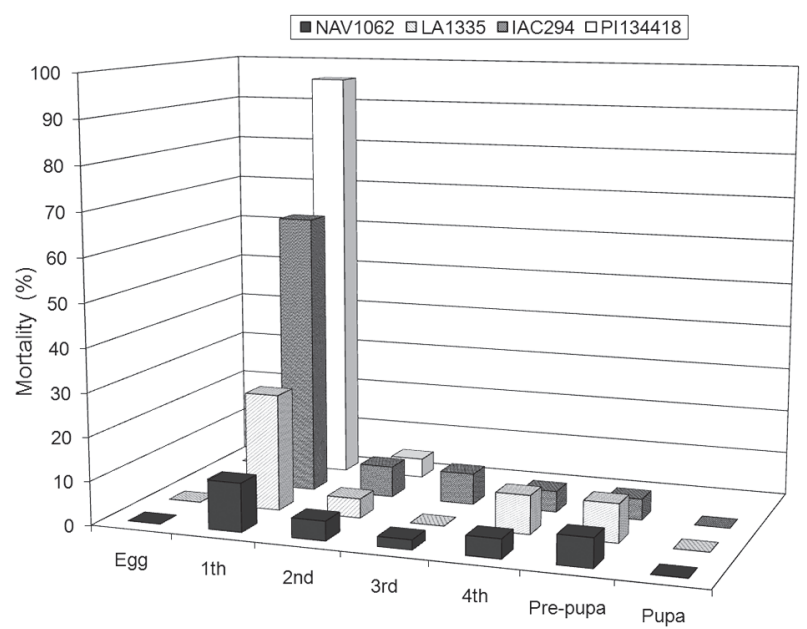

Figure $1-\%$ mortality at various stages of immature Delphastus davidsoni fed ad libitum with Bemisia tabaci B biotype eggs laid on four tomato genotypes. Temperature: $23 \pm 2{ }^{\circ} \mathrm{C}, \mathrm{RH}: 70 \pm 10 \%$, photophase: $13 \mathrm{~h}$.

and VII) have 'heads' that release allelochemicals; of these, only type VI and type VII have multicellular tips (Snyder and Carter, 1985; Channarayappa et al., 1992; Simmons and Gurr, 2005). Because of the great diversity of trichomes found on the leaf surface, some trichomes were subdivided - type $\mathrm{V}(\mathrm{Va}, \mathrm{Vb}$ and $\mathrm{Vc})$ and type $\mathrm{VI}$ (VIa, VIb and VIc) - and a new type (VIII) was characterized (Channarayappa et al., 1992).

The PI134418 genotype presented the greatest number of glandular trichomes (13.7 trichomes $\mathrm{mm}^{-2}$ ), followed by IAC294 (4.2 trichomes $\left.\mathrm{mm}^{-2}\right)$. Yet, the NAV1062 and LA1335 genotypes presented low densities of glandular trichomes $\left(0.6\right.$ and 1.5 trichomes $\mathrm{mm}^{-2}$, respectively) and high densities of nonglandular trichomes (28.5 and 9.6 trichomes $\mathrm{mm}^{-2}$, respectively), differing from PI134418 and IAC294. The NAV1062 genotype presented the highest density of total trichomes 29.2 trichomes $\left.\mathrm{mm}^{-2}\right)$, and IAC294 presented the lowest density (6.0 trichomes $\mathrm{mm}^{-2}$ ) (Table 4).

In our study, type $\mathrm{V}$ trichomes were not subdivided into $\mathrm{Va}$ and $\mathrm{Vb}$, and no type VIII trichome, as de- fined by Channarayappa et al. (1992), was identified. The counting of these trichomes may have been hampered by the technique used; it is possible that these trichomes were broken during glass slide preparation.

PI134418 had type IV $\left(11.2 \mathrm{~mm}^{-2}\right)$, VIc $\left(2.2 \mathrm{~mm}^{-2}\right)$, VII $\left(0.2 \mathrm{~mm}^{-2}\right)$ and I $\left(0.2 \mathrm{~mm}^{-2}\right)$ glandular trichomes. It also presented type $\mathrm{V}\left(1.1 \mathrm{~mm}^{-2}\right)$ nonglandular trichomes. IAC294 has type $\mathrm{V}\left(1.7 \mathrm{~mm}^{-2}\right)$ nonglandular trichomes and predominantly type IV $\left(2.0 \mathrm{~mm}^{-2}\right)$, VIc $\left(1.9 \mathrm{~mm}^{-2}\right)$, VII $\left(0.2 \mathrm{~mm}^{-2}\right)$ and I $\left(0.1 \mathrm{~mm}^{-2}\right)$ glandular trichomes. In the NAV1062 and LA1335 genotypes, type V (28.4 and $9.6 \mathrm{~mm}^{-2}$, respectively) nonglandular trichomes were predominant, followed by type VIa $\left(0.6\right.$ and $1.5 \mathrm{~mm}^{-2}$, respectively) glandular trichomes; NAV1062 also presented type II $\left(0.1 \mathrm{~mm}^{-2}\right)$ nonglandular trichomes (Figure 2).

The PI134418 and IAC294 genotypes, which had mainly types IV $(F=146.89, C V=17.94, p \leq 0.05)$ and VIc $(F=89.94, C V=11.33, p \leq 0.05)$ glandular trichomes (Figure 2), were associated with high levels of larval mortality (Figure 1), with a longer development period on IAC294 (Table 1). Conversely, genotypes with both high (NAV1062) and low (LA1335) densities of type $\mathrm{V}$ nonglandular trichomes $(F=38.14, C V=33.03, p \leq$ 0.05) (Figure 2) exhibited similar larval mortality rates (Figure 1) and development periods (Table 1).

In tomatoes, a high density of trichomes is positively correlated with B. tabaci oviposition (Heinz and Zalom, 1995; Snyder et al., 1998), notably when type V nonglandular trichomes are present. However, glandular trichomes release exudates that are able to capture whiteflies (Muigai et al., 2002; Oriani and Vendramim, 2010; Oriani et al., 2011a). Furthermore, glandular trichomes also captured a great number of first-instar of $D$. davidsoni, which were trapped by the exudates released by these trichomes. This phenomenon contributed to the high larval mortality rates observed on PI134418 (100\%) and IAC294 (88.9 \%).

In addition to contributing to the larval mortality rate of $D$. davidsoni, the presence of glandular trichomes on IAC294 may have led to the three-day increase in the larval period compared with the LA1335 and NAV1062 genotypes (Table 1). Out of the five adults that emerged on IAC294, two died during emergence, and two presented wing deformations. 
Table 4 - Mean ( \pm SE) number of trichomes $\mathrm{mm}^{-2}$ on abaxial surface of four tomato genotypes.

\begin{tabular}{lcccc}
\hline Genotypes & \multicolumn{3}{c}{ Number of trichomes $\mathrm{mm}^{-2}$} & \multirow{2}{*}{ Trichomes types } \\
\cline { 2 - 4 } & Glandular ${ }^{1}$ & Nonglandular ${ }^{1}$ & Total $^{1}$ & I, IV, V, VIc, VII \\
PI134418 & $13.7 \pm 2.83 \mathrm{a}$ & $1.1 \pm 1.62 \mathrm{c}$ & $14.8 \pm 3.95 \mathrm{~b}$ & I, IV, V, Vla, VIc, VII \\
IAC294 & $4.2 \pm 2.78 \mathrm{~b}$ & $1.7 \pm 3.19 \mathrm{c}$ & $6.0 \pm 4.53 \mathrm{c}$ & $\mathrm{V}, \mathrm{Vla}$ \\
LA1335 & $1.5 \pm 1.00 \mathrm{C}$ & $9.6 \pm 6.81 \mathrm{~b}$ & $11.1 \pm 6.69 \mathrm{bc}$ & $\mathrm{Il}, \mathrm{V}, \mathrm{Vla}$ \\
NAV1062 & $0.6 \pm 0.37 \mathrm{c}$ & $28.5 \pm 20.52 \mathrm{a}$ & $29.2 \pm 20.67 \mathrm{a}$ & \\
\hline F & $140.11^{*}$ & $38.01^{*}$ & $15.16^{*}$ & \\
CV (\%) & 14.23 & 33.13 & 24.54 & \\
\hline
\end{tabular}

Means followed by the same letters within columns are not different (Tukey test, $p \leq 0.05$ ); ${ }^{1}$ Original data; transformed in $(x+3)^{1 / 2}$ for analysis; ${ }^{*}$ Significant at $p \leq$ 0.05 ; NS - Not significant at $p \leq 0.05$.

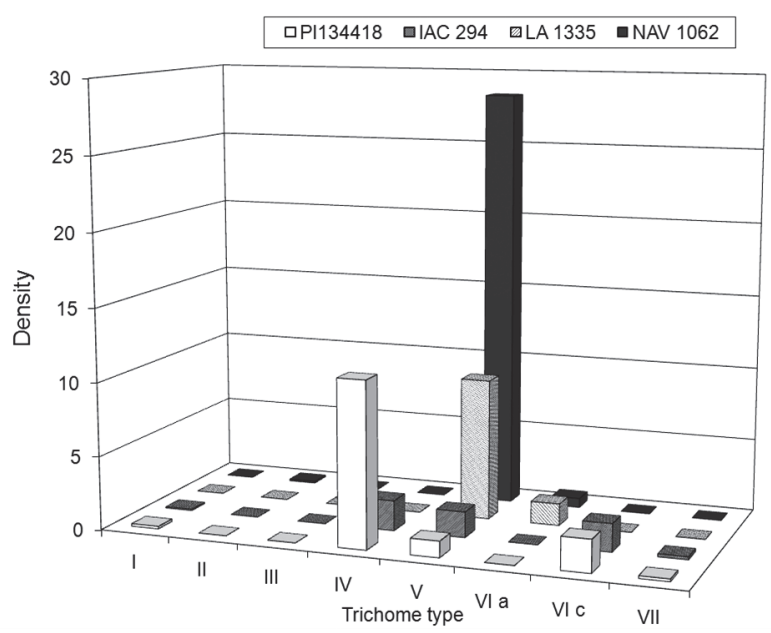

Figure 2 - Mean number of trichomes types $\mathrm{mm}^{-2}$ on abaxial surface of four tomato genotypes.

Type VIc trichomes, which are found in high densities on $S$. habrochaites f. glabratum (PI134418) and $S$. habrochaites (IAC294) (Figure 2), produce the allelochemical 2-tridecanone (2-TD), which is highly toxic to young insects. This compound causes increases in larval and pupal mortality rates and larval and pupal developmental time, in addition to pupal deformation (Leite, 2004). 2-TD also induces feeding non-preference in adult and young insects and causes oviposition non-preference (antixenosis) in other pests, including B. tabaci (Channarayappa et al., 1992), Myzus persicae (Sulzer) (Hemiptera, Aphididae) (Leite et al., 1999), Frankliniella occidentalis (Pergande) (Thysanoptera, Thripidae) (Kumar et al., 1995). Yet, the relatively small size of the first larval instars of $D$. davidsoni may have led to a greater concentration of 2-TD in their bodies, as suggested by Leite (2004), causing high larval mortality rates on PI134418 and IAC294.

One of the limitations of the use of plant resistance genotypes, especially those that have 2-TD, is the lower efficiency of biological control (Farrar and Kennedy, 1993; Barbour et al., 1993; Farrar et al., 1994). In addition to 2-TD, the alpha-tomatine present in the leaves of $S$. habrochaites f. glabratum also adversely affects Heliothis zea (Boddie) (=Helicoverpa zea (Boddie)) and Spodoptera exigua (Hübner) (Lepidoptera, Noctuidae) parasitoids (Duffey and Bloem, 1986). Thus, an additive or synergetic effect of the 2-TD and alpha-tomatine compounds present on PI134418 may have caused the total larvae mortality of $D$. davidsoni (Figure 1).

The searching capacity of Chrysoperla externa (Hagen) (Neuroptera, Chrysopidae) (Toscano et al., 2003) and Podisus nigrispinus (Dallas) (Hemiptera, Pentatomidae) (De Clercq et al., 2000) was also adversely affected by the presence of glandular trichomes on tomato genotypes. Host plants may influence predation efficiency either directly or indirectly, due to either a change in prey susceptibility or predator success in searching for its prey (Obrycki and Kring, 1998). Thus, the trichomes may influence the behavior and predation ability of natural enemies (Hare, 1992; Guershon and Gerling, 2006), and predator efficiency may be adversely affected due to an increase in searching time for the prey (Botrell et al., 1998). On the other hand, the high density of type $\mathrm{V}$ nonglandular trichomes did not interfere in the larvae development time; low larval mortality was observed on the NAV1062 genotype (28.8\%). In an experiment including 18 tomato genotypes, Oriani et al. (2011a) observed that NAV1062 (S. pimpinellifolium) presented the second greatest density of nonglandular trichomes 159.5 $\left.\mathrm{mm}^{-2}\right)$, lower only in number recorded for LA1963 genotype (S. chilense) $\left(63.7 \mathrm{~mm}^{-2}\right)$.

The coccinellid species may be more efficient on pubescent plants (Shah, 1982). Heinz and Zalom (1996) verified that the residence time of $D$. pusillus on tomato genotype was higher on 'Alta' (pubescent) than on 'VF145B7879' (glabrous), thereby compensating for the lower predator efficiency and fecundity. Additionally, the differences in predator activity on tomentose vs. glabrous leaves indicate that the main behaviors that generally lead to predation (e.g., walking, handling, feeding) are less visible and more interrupted on the tomentose than on glabrous leaves by D. pusillus (Guershon and Gerling, 1999).

In conclusion, types IV and VI glandular trichomes present on PI134418 and IAC294 genotypes adversely affected the larval development of $D$. davidsoni, causing extremely high larval mortality. Conversely, type 
$\mathrm{V}$ nonglandular trichomes (the most common trichome on tomato genotypes), at both high (NAV1062) and low (LA1335) density, did not affect insect development.

\section{Acknowledgements}

To the Brazilian National Council for Scientific and Technological Development (CNPq) for a research fellowship and to Guillermo González F. who determined the coccinellid species as Delphastus davidsoni.

\section{References}

Barbour, J.D.; Farrar Jr., R.R.; Kennedy, G.G. 1993. Interaction of Manduca sexta resistance in tomato with insect predators of Helicoverpa zea. Entomologia Experimentalis et Applicata 68: 143-155.

Barbour, J.D.; Farrar Jr., R.R.; Kennedy, G.G. 1997. Populations of predaceous natural enemies developing on insect-resistant and susceptible tomato in North Carolina. Biological Control 9: 173-184.

Botrell, D.G.; Barbosa, P.; Gould, F. 1998. Manipulating natural enemies by plant variety selection and modification: a realistic strategy? Annual Review of Entomology 43: 347-367.

Channarayappa, S.G.; Muniyappa, V.; Frist, R.H. 1992. Resistance of Lycopersicon species to Bemisia tabaci, a tomato leaf curl virus vetor. Canadian Journal of Botany 70: 2184-2192.

De Clercq, P.; Mohaghegh, J.; Tirry, L. 2000. Effect of host plant on the functional response of the predator Podisus nigrispinus (Heteroptera: Pentatomidae). Biological Control 18: 65-70.

Duffey, S.S.; Bloem, K.A. 1986. Plant defense-herbivore parasite interactions and biological control. p. 135-183. In: Kogan, M., ed. Ecological theory and integrated pest management. Wiley, New York, NY, USA.

Farrar Jr., R.R.; Kennedy, G.G. 1993. Field cage performance of two tachinid parasitoids of the tomato fruitworm on insect resistant and susceptible tomato lines. Entomologia Experimentalis et Applicata 67: 73-78.

Farrar Jr., R.R.; Barbour, J.D.; Kennedy, G.G. 1994. Field evalution of insect resistance in a wild tomato and its effects on insect parasitoids. Entomologia Experimentalis et Applicata 71: 211-226.

Frank, J.H.; Mizell, R.F. 2004. Ladybirds, Ladybird Beetles, Lady Beetles, Ladybugs of Florida, Coleoptera: Coccinellidae. University of Florida, Gainesville, FL, USA. Available at: http:// edis.ifas.ufl.edu/pdffiles/IN/IN32700.pdf [Accessed Sept 28, 2013]

Guershon, M.; Gerling, D. 1999. Predatory behavior of Delphastus pusillus in relation to the phenotypic plasticity of Bemisia tabaci nymphs. Entomologia Experimentalis et Applicata 92: 239-248.

Guershon, M.; Gerling, D. 2006. Effects of plant and prey characteristics on the predatory behavior of Delphastus catalinae. Entomologia Experimentalis et Applicata 121: 15-21.

Hare, J.D. 1992. Effects of plant variation on herbivore-natural enemy interactions. p. 283-284. In: Fritz, R.S.; Simms, E.L., eds. Plant resistance to herbivorous and pathogens: ecology, evolution and genetics. University of Chicago Press, Chicago, IL, USA.
Heinz, K.M.; Brazzle, J.R.; Pickett, C.H.; Natwick, E.T.; Nelson, J.M.; Parrella, M.P. 1994. Predatory beetle may suppress silverleaf whitefly. California Agriculture 48: 35-40.

Heinz, K.M.; Parrella, M.P. 1994. Poinsettia (Euphorbia pulcherrima Willd. ex Koltz.) cultivar-mediated in performance of five enemies of Bemisia argentifolii Bellows and Perring, n. sp. (Homoptera: Aleyrodidae). Biological Control 4: 305-318.

Heinz, K.M.; Zalom, F.G. 1995. Variation in trichome-based resistance to Bemisia argentifolii (Homoptera, Aleyrodidae) oviposition on tomato. Journal of Economic Entomology 88: 1494-1502.

Heinz, K.M.; Zalom, F.G. 1996. Performance of the predator Delphastus pusillus on Bemisia resistant and susceptible tomato lines. Entomologia Experimentalis et Applicata 81: 345-352.

Hodek, I.; Honěk, A. 2009. Scale insects, mealybugs, whiteflies and psyllids (Hemiptera, Sternorrhyncha) as prey of ladybirds. Biological Control 51: 232-243.

Hoelmer, K.A.; Osborne, L.S.; Yokomi, R.K. 1993. Reproduction and feeding behavior of Delphastus pusillus (Coleoptera: Coccinellidae), a predator of Bemisia tabaci (Homoptera: Aleyrodidae). Journal of Economic Entomology 86: 322-329.

Hoelmer, K.A.; Pickett, C.H. 2003. Geographic origin and taxonomic history of Delphastus spp. (Coleoptera: Coccinellidae) in commercial culture. Biocontrol Science Technology 13: 529535.

Kumar, N.K.K.; Ullman, D.E.; Cho, J.J. 1995. Resistance among Lycopersicon species to Frankliniella occidentalis (Thysanoptera: Thripidae). Journal of Economic Entomology 88: 1057-1065.

Legaspi, J.C.; Legaspi, B.C.; Simmons, A.M.; Soumare, M. 2008. Life table analysis for immatures and female adults of the predatory beetle, Delphastus catalinae, feeding on whiteflies under three constant temperatures. Journal of Insect Science 8: 1-9.

Legaspi, J.C.; Simmons, A.M.; Legaspi, B.C. 2006. Prey preference by Delphastus catalinae (Coleoptera: Coccinellidae) on Bemisia argentifolii (Homoptera: Aleyrodidae): effects of plant species and prey stages. Florida Entomologist 89: 218-222.

Leite, G.L.D. 2004. Tomato resistance to pests. Unimontes Científica 6: 129-140 (in Portuguese, with abstract in English).

Leite, G.L.D.; Picanço, M.; Guedes, R.N.C.; Skowronski, L. 1999. Effect of fertilization levels, age and canopy height of Lycopersicon hirsutum on the resistance to Myzus persicae. Entomologia Experimentalis et Applicata 91: 267-273.

Liu, T.X. 2005. Life history and life table analysis of the whitefly predator Delphastus catalinae (Coleoptera: Coccinellidae) on collards. Insect Science 12: 129-135.

Lopez-Avila, A. 1986. Natural enemies. p. 27-35. In: Cock, M.J.W., ed. Bemisia tabaci: a literature survey of the cotton whitefly with an annotated bibliography. CABI, Wallingford, UK.

Luckwill, L.L.C. 1943. The genus Lycopersicon: An Historical, Biological, and Taxonomic Survey of the Wild and Cultivated Tomatoes. Aberdeen University Press, Aberdeen, Scotland.

McAuslane, H.J. 1996. Influence of leaf pubescence on ovipositional preference of Bemisia argentifolii (Homoptera, Aleyrodidae) on soybean. Environmental Entomology 25: 834841.

Muigai, S.G.; Schuster, D.J.; Bassett, M.J.; Scott, J.W.; McAuslane, H.J. 2002. Mechanisms of resistance in Lycopersicon germplasm to the whitefly Bemisia argentifolii. Phytoparasitica 30: 347-360. 
Obrycki, J.J.; Kring, T.J. 1998. Predaceous Coccinellidae in biological control. Annual Review of Entomology 43: 295-321.

Obrycki, J.J.; Tauber, M.J. 1984. Natural enemy activity on glandular pubescent potato plants in the greenhouse: an unreliable predictor of effects in the field. Environmental Entomology 13: 679-683.

Oliveira, M.R.V.; Amancio, E.; Laumann, R.A.; Gomes, L.O. 2003. Natural enemies of Bemisia tabaci (Gennadius) B biotype and Trialeurodes vaporariorum (Westwood) (Hemíptera: Aleyrodidae) in Brasília, Brazil. Neotropical Entomology 32: 151-154.

Oriani, M.A.G.; Vendramim, J.D. 2010. Influence of trichomes on attractiveness and ovipositional preference of Bemisia tabaci (Genn.) biotype B (Hemiptera, Aleyrodidae) on tomato genotypes. Neotropical Entomology 39: 1002-1007.

Oriani, M.A.G.; Vendramim, J.D.; Vasconcelos, C.J. 2011a. No-choice ovipositional non preference of Bemisia tabaci (Gennadius) B biotype on tomato genotypes. Scientia Agricola 68: $147-153$

Oriani, M.A.G.; Vendramim, J.D.; Vasconcelos, C.J. 2011 b. Aspects of the biology of Bemisia tabaci (Genn.) B biotype (Hemiptera, Aleyrodidae) on 18 tomato genotypes. Scientia Agricola 68: 37-41.

Peralta, I.E.; Knapp, S.; Spooner, D.M. 2006. Nomenclature for wild and cultivated tomatoes. Report of the Tomato Genetics Cooperative 56: 6-12.

Pickett, C.H.; Casanave, K.A.; Schoenig, S.E.; Heinz, K.M. 1999. Rearing Delphastus catalinae (Coleoptera: Coccinellidae): practical experience and a modeling analysis. Canadian Entomologist 131: 115-129.

Price, P.W. 1986. Ecological aspects of host plant resistance and biological control: interaction among three trophic level. p. 1136. In: Boethel, D.J.; Eikenbary, R.D., eds. Interaction of plant resistance and parasitoids and predators of insects. Wiley, New York, NY, USA.
Segatto, F.B.; Bisognin, D.A.; Benedetti, M.; Costa, L.C.; Rampelotto, M.V.; Nicoloso, F.T. 2004. A technique for the anatomical study of potato leaf epidermis. Ciência Rural 34: 1597-1601 (in Portuguese, with abstract in English).

Shah, M.A. 1982. The influence of plant surfaces on the searching behavior of coccinelid larvae. Entomologia Experimentalis et Applicata 31: 377-380.

Simmons, A.T.; Gurr, G.M. 2005. Trichomes of Lycopersicon species and their hybrids: effects on pest and natural enemies. Agricultural and Forest Entomology 7: 265-276.

Snyder, J.C.; Carter, C.D. 1985. Trichomes on leaves of Lycopersicon hirsutum L. esculentum and their hybrids. Euphytica 34: 53-64.

Snyder, J.C.; Simmons, A.T.; Tracker, R.R. 1998. Attractancy and ovipositional response of adult Bemisia argentifolii (Homoptera: Aleyrodidae) to type IV trichome density on leaves of Lycopersicon hirsutum grown in three daylength regimes. Journal of Entomological Science 33: 270-281.

Toscano, L.C.; Auad, A.M.; Figueira, L.K. 2003. Behavior of Chrysoperla externa (Hagen, 1861) in tomato genotypes infested with eggs of Bemisia tabaci (Gennadius, 1889) biotype b. Arquivos do Instituto Biológico 70: 117-121 (in Portuguese, with abstract in English).

Vendramim, J.D. 2002. Biological control and host plant resistance. p. 511-528. In: Parra, J.R.P.; Botelho, P.S.M.; Corrêa-Ferreira, B.S.; Bento, J.M.S., eds. Biological control in Brazil: parasitoids and predators. Manole, São Paulo, SP, Brazil.

Verkerk, R.H.J.; Leather, S.R.; Wright, D.J. 1998. The potential for manipulating crop-pest-natural enemy interactions for improved insect pest management. Bulletin of Entomological Research 88: 493-501. 